American Journal of Applied Sciences 4 (10): 768-773, 2007

ISSN 1546-9239

(C) 2007 Science Publications

\title{
Engineering Properties and Compressibility Behavior of Tropical Peat Soil
}

\author{
${ }^{1}$ Youventharan Duraisamy, ${ }^{2}$ Bujang B.K. Huat and ${ }^{2}$ Azlan A. Aziz \\ ${ }^{1}$ University Malaysia Pahang, Malaysia \\ ${ }^{2}$ University Putra Malaysia, Serdang, Selangor, Malaysia
}

\begin{abstract}
This paper presents the engineering properties and compressibility behavior of various types of tropical peat soil collected from several locations in Malaysia. These soils represented fibric, hemic and sapric type of tropical peat with organic content ranging from $70 \%$ to $90 \%$. The correlations of the various basic engineering properties of the tropical peat soils have been found to be close and new equations have been established. Loss on ignition (Organic Content) appears to be a very useful parameter for the peat. It correlates well with the natural water content, liquid limit, density and specific gravity. Compressibility behavior of various type of peat soil was measured using Rowe Cell consolidation test for accuracy and conventional oedometer test for comparison purpose. Compressibility index $\mathrm{Cc}$ and $\mathrm{C} \alpha$ was identified as two crucial parameters to estimate settlements in peat soil. Parametric study has been carried out at the end of the study to foresee the effect of surcharge on fibric, hemic and sapric peat ground. Based on the results obtained, it shows that fibric peat recorded the highest settlement followed by hemic and sapric peat with increase in consolidation pressure.
\end{abstract}

Keywords: Coefficient of secondary compression, compression index, organic soil, peat soil, Rowe Cell consolidation.

\section{INTRODUCTION}

Peat is an organic soil which consists more than $70 \%$ of organic matters. Peat deposits are found where conditions are favorable for their formation. In Malaysia, some 3 million hectares of land is covered with peat. Peat poses serious problems in construction due to its long-term consolidation settlements even when subjected to a moderate $\operatorname{load}^{[1]}$. Hence, peat is considered unsuitable for supporting foundations in its natural state.

Various construction techniques have been carried out to support embankments over peat deposits without risking bearing failures but settlement of these embankments remains excessively large and continues for many years. Besides settlement, stability problems during construction such as localized bearing failures and slip failures need to be considered.

Experimental Design and Laboratory Work: The main objective of this study is to examine the peculiar engineering behavior of tropical peat with respect to their compressibility characteristics due to variation in fiber content and organic content. Meanwhile the index properties such as natural water content, organic content, liquid limit, specific gravity and density of various type of tropical peat were obtained to establish suitable correlation. Understanding the engineering properties and compressibility characteristics of peat will give hand for the engineers in determining suitable ground improvement method. Thus, proper construction and foundation design guide for various type of peat could be outlined for future developments in peat soils.

Sample preparation: Undisturbed samples of peat soil were taken from three different locations on the West coast of Peninsular Malaysia by using the sampling tube. First the undisturbed soil samples were transferred directly from the sampling tube into the ring. A suitable auger was designed and fabricated to collect undisturbed peat samples as shown in Fig. 1. The auger enables the extraction of peat core sample of $150 \mathrm{~mm}$ diameter by $230 \mathrm{~mm}$ length. The top and bottom of the specimen was trimmed. Fibrous soil such as peat is easily disturbed therefore the trimming process was carried out carefully. Furthermore, the trimming

Corresponding Author: Bujang B.K. Huat, Faculty of Engineering, Universiti Putra Malaysia, 43000 Serdang Selangor. Tel: 603-89466368, Fax: 603-86567129 
process was carried out quickly to minimize a change in the water content of the soil sample.

Sample was then tested using Rowe Cell to overcome most of the disadvantages of the conventional oedometer apparatus when performing consolidation tests on low permeability soils, including non uniform deposits. The most important features are the ability to control drainage and to measure pore water pressure during the course of consolidation tests. Fig. 2 shows the experimental set up of using Rowe Cell. Size of the cell used in this research was $150 \mathrm{~mm}$ in diameter and $50 \mathrm{~mm}$ in height. The hydraulic loading system pressure to be applied and vertical load can be applied to the sample surface either via a flexible diaphragm to give a uniformly distributed pressure(free strain) or via a rigid plate to give uniform settlement (equal strain). However for the purpose of comparison study, conventional oedometer test was carried out too. The size of the ring used was $50 \mathrm{~mm}$ in diameter and 20 $\mathrm{mm}$ in height.

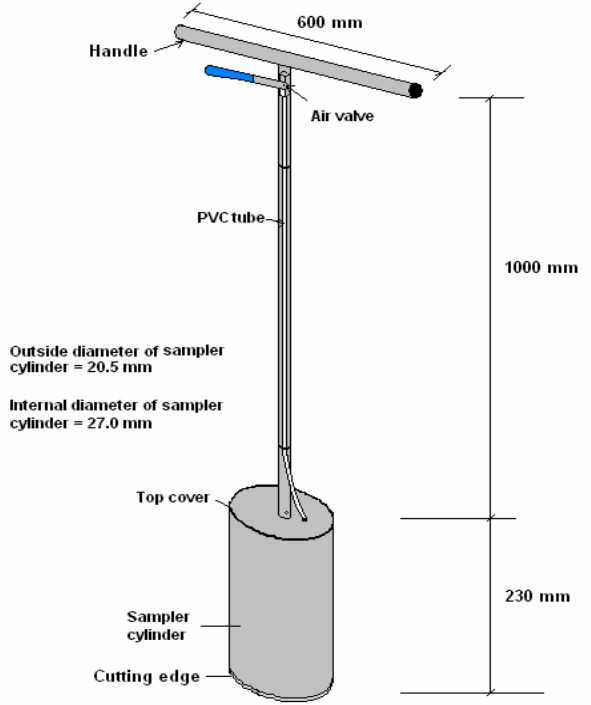

Fig. 1: UPM Peat sampler

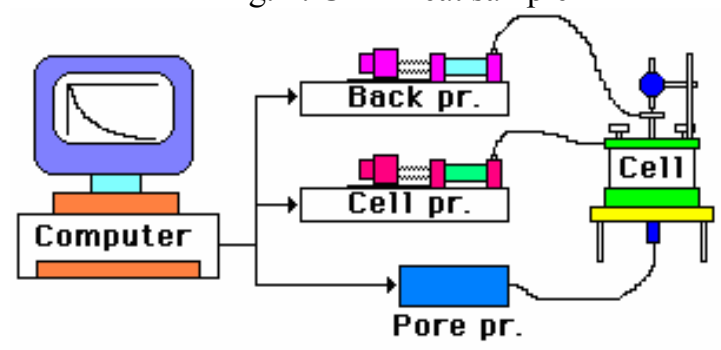

Fig. 2: Rowe Cell consolidation test set up
Load increment was applied at 20,40,80,160, and 320 $\mathrm{kN} / \mathrm{m}^{2}$. Additional load was placed on the soil specimen to determine the soil behavior at higher pressure. Each load increment was maintained for 24 hours. Back pressure of $200 \mathrm{kN} / \mathrm{m}^{2}$ was maintained through out the test.

Testing programs: Index properties of peat soil used in the classification system of peat namely the water content, organic content, specific gravity, fiber content, degree of humification and Atterberg limits were determined based on test procedures according to the British Standard BS1377: 1990, 'Methods of test for soils for civil engineering purposes'. Apart from the classifying tests, compressibility behavior of the peat soil was determined by conventional oedometer test and Rowe Cell consolidation test.

\section{RESULTS AND DISCUSSION}

One of the main objectives of this study is to find the relationship between the basic geotechnical properties of peat soil with index parameters such as natural water content, organic content and liquid limit. It must also be appreciated that compared with soils of mineral origin, the peat soils, in particular those of the tropical genesis, have only recently been given attention. As such even determination methods of some of the basic properties are still being researched. In some cases no consensus has been reached, either with respects to the methods, nor details of any given methods. However, for ease of comparison, the apparently most commonly used methods of determination of soil basic properties are used in this study.

Soil description: Peat sample was obtained from marine and continental deposits on the West coast of Peninsular Malaysia. It consists primarily of low plasticity fines, some fine to medium sands and it is dark brown in color. Based on results of characterization tests performed it ranges from three different type of peat according to the USDA classification system and Von Post Scale. Soil characterization test were performed on each soil sample in accordance with accepted BS 1377: 1990 and ASTM procedures. The results of the characterization tests are in Table 1. The Atterberg limits were determined on the soil particles passing the $475 \mu \mathrm{m}$ sieve. As seen in Table 1, fairly significant increase in liquid limit with the increase in natural water content. Huat ${ }^{[2]}$ stated 
Table 1: Index properties of peat samples

\begin{tabular}{ccccccccccc}
\hline BH & $\begin{array}{l}\text { Water } \\
\text { Content } \\
(\%)\end{array}$ & $\begin{array}{l}\text { Liquid } \\
\text { Limit } \\
(\%)\end{array}$ & $\begin{array}{l}\text { Organic } \\
\text { Content } \\
(\%)\end{array}$ & $\begin{array}{l}\text { Von Post } \\
\text { Scale }\end{array}$ & $\begin{array}{l}\text { Fiber } \\
\text { Content } \\
(\%)\end{array}$ & $\begin{array}{l}\text { Specific } \\
\text { Gravity }\end{array}$ & $\begin{array}{l}\text { Void } \\
\text { ratio, e }\end{array}$ & $\begin{array}{l}\text { Dry } \\
\text { Density, } \\
\left(\mathrm{Mg} / \mathrm{m}^{3}\right)\end{array}$ & $\begin{array}{l}\text { Bulk } \\
\text { Density, } \\
\left(\mathrm{Mg} / \mathrm{m}^{3}\right)\end{array}$ & $\begin{array}{l}\text { Peat } \\
\text { Type }\end{array}$ \\
\hline 1 & 266 & 285 & 76 & H5 & 65 & 1.52 & 7.541 & 0.170 & 0.922 & Hemic \\
2 & 330 & 350 & 84 & H4 & 75 & 1.45 & 9.535 & 0.147 & 0.834 & Fibric \\
3 & 350 & 398 & 88 & H4 & 77 & 1.42 & 10.48 & 0.136 & 0.811 & Fibric \\
4 & 181 & 250 & 73 & H7 & 55 & 1.55 & 5.522 & 0.238 & 1.008 & Hemic \\
5 & 241 & 275 & 75 & H6 & 58 & 1.53 & 6.536 & 0.192 & 0.856 & Hemic \\
6 & 140 & 240 & 70 & H8 & 32 & 1.56 & 4.125 & 0.283 & 1.019 & Sapric \\
7 & 286 & 310 & 77 & H5 & 68 & 1.51 & 7.895 & 0.170 & 0.956 & Fibric \\
8 & 300 & 330 & 80 & H8 & 31 & 1.49 & 4.824 & 0.249 & 0.996 & Sapric \\
\hline
\end{tabular}

that the natural water content of peat in West Malaysia ranges from $200 \%$ to $700 \%$ and with organic content in the range of $50 \%$ to $95 \%$. The recorded values in the above table fulfill this statement. Further more the liquid limit was in the range of $200 \%$ to $500 \%$ as reported by Huat ${ }^{[2]}$. Engineering properties such as specific gravity, dry density and bulk density of the samples were within the range as reported by Huat ${ }^{[2]}$. The bulk densities of peat are in the range of $0.8-1.2$ $\mathrm{Mg} / \mathrm{m}^{3}$ whereas the dry densities are $0.1-1.4 \mathrm{Mg} / \mathrm{m}^{3}$. Specific gravity falls in the range of $1.07-1.7$ and an average of about 1.4. In addition to basic characterization tests, comparison study of the engineering properties obtained from laboratory works with the theoretical values were done.

Correlations of index properties: As mentioned before, one of the main objectives of the paper is to study the relationship of the basic geotechnical properties of tropical peat soils with some of the easily determined parameters such as natural water content, organic content or liquid limit. Comparison is made with the published correlations of the more established organic soils of the temperate genesis. These are described below.

Fig. 3 shows the empirical relationships between organic content $(O C)$ and liquid limit $(L L)$ which have been proposed by Skempton and Petley ${ }^{[3]}$ for temperate peat. However Eq. (1) does not seem to fit well in the case of tropical peat. For the case of tropical peat studied in Malaysia, the best fit line of the samples is given in Eq. (2) (LL and OC in percent). Liquid limit of the tropical peat soils was found to range from 150 $400 \%$. In general the liquid limit of peat increases with increase in organic content

$\mathrm{LL}=0.5+5.0 \mathrm{OC}$

$\mathrm{LL}=0.3+3.0 \mathrm{OC}$

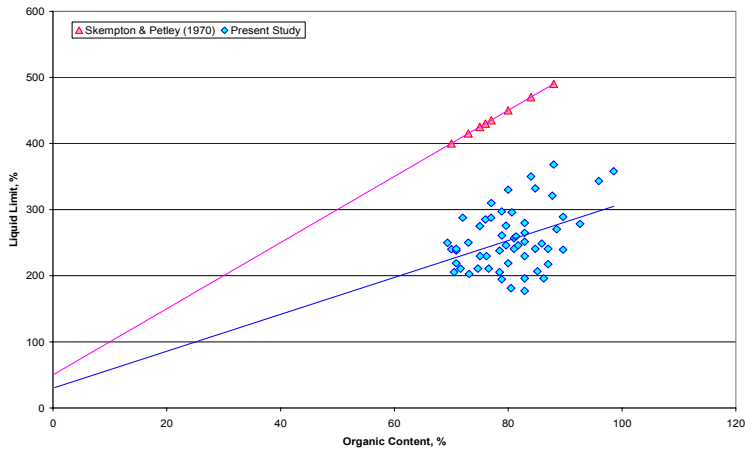

Fig. 3: Liquid limit versus organic content

Fig. 4 shows the relationship of dry density $\left(\rho_{d}\right)$ and natural water content $(w)$. For temperate peat soils in the district of central Netherlands, the best fit line is given by Eq. (3), proposed by Den Haan ${ }^{[4]}$. Data collected from the tropical peat sample was plotted on the same figure and both the sample fit close to each other. However for identification of tropical peat, a special equation was form as Eq. (4).

$\rho_{\mathrm{d}}=35.075(\mathrm{w})^{-0.856}$
$\rho_{\mathrm{d}}=22.422(\mathrm{w})^{-0.804}$

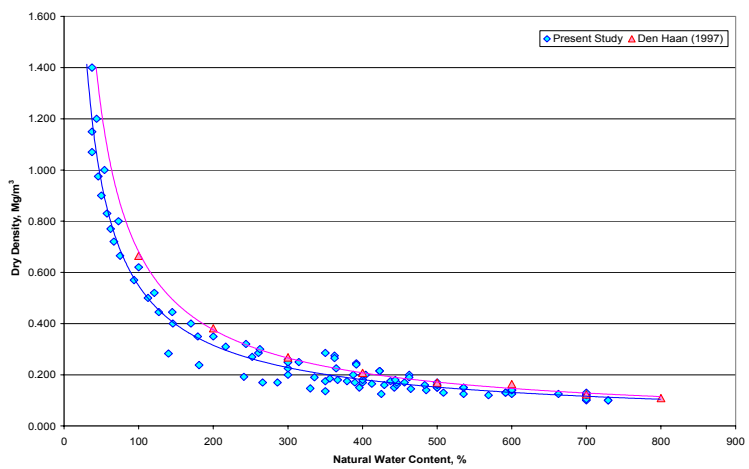

Fig. 4: Dry density versus natural water content 
Specific gravity in peat soils are affected by the organic constituents, and cannot therefore simply be set to somewhere near $2.65-2.75$ as for in mineral soils. Den $\mathrm{Haan}^{[4]}$ for example quoted cellulose and lignin to have specific gravity of approximately 1.58 and 1.40 respectively. These low values would as expected reduces the compounded specific gravity of organic soils. Fig. 5 shows the variation of specific gravity with organic content using correlation proposed by Kaniraj and Joseph $^{[5]}$ using Eq. (5), Huat ${ }^{[2]}$ using Eq. (6), Skempton and Petley ${ }^{[3]}$ using Eq. (7) and Den Haan ${ }^{[4]}$ using Eq. (8). Experimental results plotted for specific gravity of tropical peat, fit closely with Eq. 8 proposed by Den Haan ${ }^{[4]}$. Thus an equation was form to establish the identification process of tropical peat soil.

$$
\begin{aligned}
& \mathrm{Gs}=-1.6281 O C+2.6859 \\
& \mathrm{Gs}=-1.2 O C+2.7 \\
& \mathrm{Gs}=1 /(0.358 O C+0.357) \\
& \mathrm{Gs}=1 /(0.362 O C+0.371)
\end{aligned}
$$

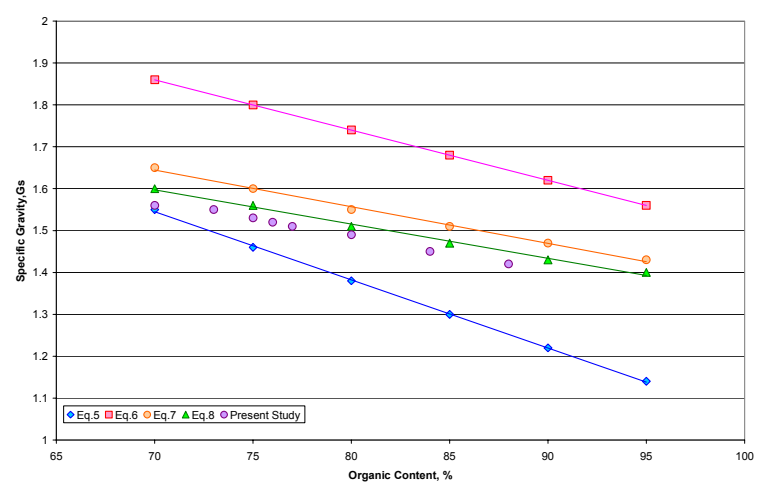

Fig. 5: Specific gravity versus organic content

Compressibility: The following section presents the results of consolidation parameters using Conventional Oedometer test and Rowe Cell Consolidation test. Study was focused on two consolidation parameters which are Compression Index $(\mathrm{Cc})$ and Coefficient of Secondary Compression $(\mathrm{C} \alpha)$. Three types of peat which are fibric, hemic and sapric peat were used in the research.

Compression index, Cc: Based on Fig. 6, the compression index $(\mathrm{Cc})$ values from Rowe Cell consolidation test for fibric peat were within the range of 1.878 to 3.627 for consolidation pressure of $40 \mathrm{kPa}$ to $320 \mathrm{kPa}$. Values of $\mathrm{Cc}$ for hemic peat were recorded as 1.34 to 2.99 and sapric peat was 1.24 to 2.63 . These values were from Rowe Cell consolidation test and measured higher than the values from conventional oedometer test results. Results from conventional oedometer test considered far less reliable because back pressure was not induced and pore water pressure was not measured during the course of the test. The compression index $(\mathrm{Cc})$ values from conventional oedometer test for fibric was 1.453 to 3.211 , hemic was 1.29 to 2.78 and sapric was 1.15 to 2.44 . However these values are far smaller than what has been reported for $\mathrm{Cc}$ value of peat as 5 to 10 in the literature. Regardless of type of peat, samples collected from this tropical region possess high compressibility when subjected to higher loading over the time period.

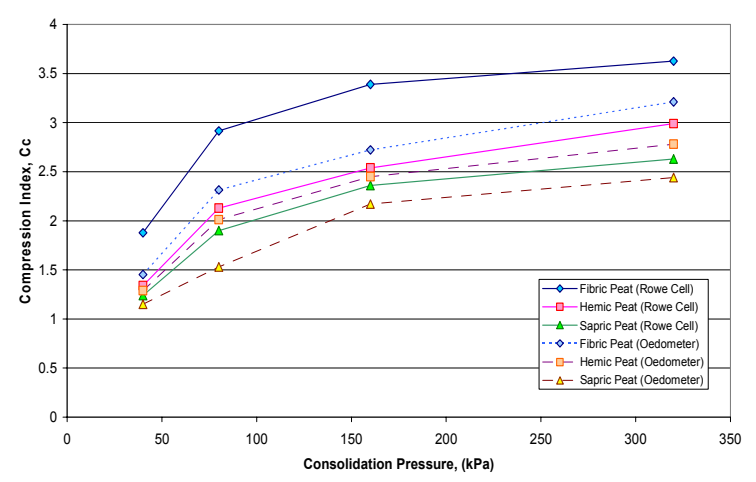

Fig. 6: Compression index versus consolidation pressure

Coefficient of secondary compression, $\mathrm{Ca}$ : Based on Fig. 7, the coefficient of secondary compression $(\mathrm{C} \alpha)$ values from Rowe Cell consolidation test for fibric peat was within the range of 0.0608 to 0.0985 for consolidation pressure of $40 \mathrm{kPa}$ to $320 \mathrm{kPa}$. Values of $\mathrm{C} \alpha$ for hemic peat were recorded as 0.0585 to 0.0959 and sapric peat was 0.0544 to 0.0939 . These values were from Rowe Cell consolidation test and measured higher than the values from conventional oedometer test results. Results from conventional oedometer test considered far less reliable because back pressure was not induced and pore water pressure was not measured during the course of the test. The coefficient of secondary compression $(\mathrm{C} \alpha)$ value from conventional oedometer test for fibric was 0.0374 to 0.0901 , hemic was 0.0225 to 0.0881 and sapric was 0.014 to 0.0851 . According to Mesri ${ }^{[6]}$, soil with C $\alpha$ values of more than 0.064 is classified as soil with extremely high secondary compressibility. The coefficient of secondary compression $C_{\alpha}(=\Delta e / \Delta \log t)$ was determined from the slope of the $e-\log t$ curves during the period of 4 to 24 hours after load increment, assuming that the secondary compression would have started 4 hours after loading. 
Table 2: Summary of compression parameters and predicted consolidation settlements

\begin{tabular}{cllllll}
\hline $\begin{array}{c}\text { Sample } \\
\text { Type }\end{array}$ & Test Type & $\begin{array}{l}\text { Compression } \\
\text { Index, } C_{C}\end{array}$ & $\begin{array}{l}\text { Compression } \\
\text { Ratio, } \\
C_{C} / 1+e_{o}\end{array}$ & $\begin{array}{l}\text { Coefficient of } \\
\text { Secondary } \\
\text { Compression, } \\
C c\end{array}$ & $\begin{array}{l}\text { Law of } \\
\text { Compressibility, } \\
\text { C } \alpha / C c\end{array}$ & $\begin{array}{l}\text { Predicted } \\
\text { Consolidation } \\
\text { Settlements } \\
(\mathrm{m})\end{array}$ \\
\hline Fibric & Rowe Cell & 2.752 & 0.422 & 0.0608 & 0.0283 & 2.32 \\
Hemic & Rowe Cell & 2.165 & 0.253 & 0.0585 & 0.0356 & 1.82 \\
Sapric & Rowe Cell & 1.935 & 0.217 & 0.0544 & 0.0380 & 1.63 \\
Fibric & Oedometer & 2.332 & 0.358 & 0.0637 & 0.027 & 1.97 \\
Hemic & Oedometer & 2.035 & 0.238 & 0.0553 & 0.027 & 1.72 \\
Sapric & Oedometer & 1.795 & 0.202 & 0.0495 & 0.027 & 1.51 \\
\hline
\end{tabular}

The $C_{\alpha}$ increases as the consolidation pressure is increased. Similar trend was observed with samples tested using oedometer. Thus peat samples used in this research will cause high secondary settlements with the increase in loading over the time period.

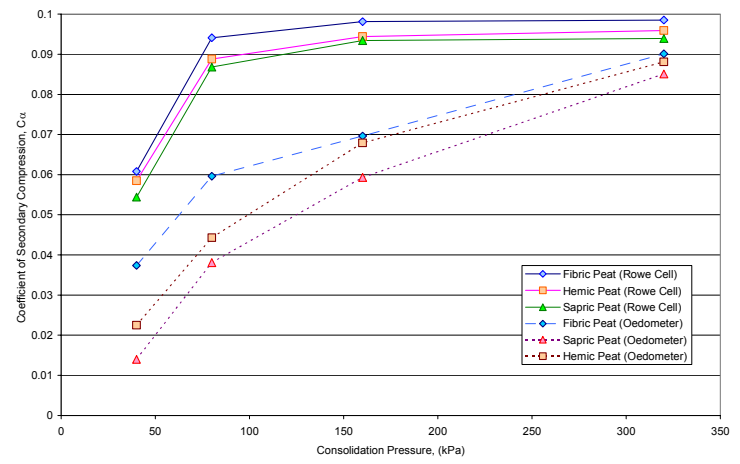

Fig. 7: Coefficient of secondary compression versus consolidation pressure

Compression ratio: Parameter $\mathrm{C}_{\mathrm{C}} / 1+\mathrm{e}_{\mathrm{o}}$ is called compression ratio. According to $\mathrm{O}^{\prime}$ Loughlin and Lehane $^{[7]}$, compression ratio for peat in the range of 0 to 0.05 is classified as very slightly compressible followed by slightly compressible for anything in between 0.05 to 0.10 . Moderately compressible peat lies in the range of 0.10 to 0.20 and very compressible peat has ratio in between 0.20 to 0.35 . Based on the compression ratios given in Table 2, all the three type of tropical peat regardless of type of test used was classified as very compressible $(>0.20)$.

Law of compressibility: Mesri and Castro ${ }^{[8]}$ reported that the value of $C_{\alpha} / C_{c}$ law for peat and muskeg lies in the range of 0.05 to 0.07 . Based on Table 2, value of $C_{a} / C_{c}$ law for tropical peat determined from conventional oedometer test was about 0.027 for fibric, hemic and sapric. Whereas samples tested using Rowe Cell consolidation was recorded in the range of 0.02 to 0.04 . These values are generally not in agreement with the values reported in literature. Since the value of $C_{\alpha} / C_{c}$ law for tropical peat is lower than the value of $C_{\alpha} / C_{c}$ law reported in the literature, less creep settlement develops when the tropical peat is loaded. However, this need to be verified with further research works involving long-term consolidation test. A parametric study was conducted assuming a normally consolidated $5 \mathrm{~m}$ depth peat ground with embankment. Using one dimensional consolidation theory and Anglo Saxon method, ultimate consolidation settlements were predicted as in Table 2. Based on the results obtained, it shows that fibric peat recorded the highest settlements followed by hemic and sapric.

\section{CONCLUSION}

The following are the main observations drawn from the index test and consolidation test described in this paper:

1. Based on the experimental data obtained in the laboratory, dry density and specific gravity values of tropical peat correlate well with the equation proposed by Den Haan ${ }^{[4]}$.

2. Coefficient of secondary compression $(\mathrm{C} \alpha)$ values of fibric, hemic and sapric of tropical peat are in the range of 0.08 to 0.09 . These values are indicative of soil with extremely high secondary compressibility.

3. Compression ratio $\left(\mathrm{C}_{\mathrm{C}} / 1+\mathrm{e}_{\mathrm{o}}\right)$ of fibric, hemic and sapric are in the range of 0.2 to 0.4 and classified as very compressible.

4. The $C_{\alpha} / C_{c}$ law value of fibric, hemic and sapric peat of tropical are in the range of $0.02-0.04$. It is smaller than the value 0.05 to 0.07 suggested by Mesri and Castro ${ }^{[8]}$

5. Tropical fibric peat will cause highest settlements followed by hemic and sapric when subjected to any load over the time period. 


\section{ACKNOWLEDGMENT}

Financial assistance from the Ministry of Science, Technology and Innovation Malaysia (MOSTI), as Research Grant to the second author and Scholarship from University Malaysia Pahang to the first author are gratefully acknowledged. A special tribute goes to Mrs. Ernaleza Mahsum (Research Assistant) for her industrious work.

\section{REFERENCES}

1. Jarret, P.M. 1995. Geoguide 6. Site Investigation for Organics Soils and Peat. JKR Document 20709-0341-95. Institut Kerja Raya Malaysia.

2. Huat, B.K. 2004. Organic and Peat Soils Engineering. Serdang: University Putra Malaysia Press.

3. Skempton, A. W. and D. J. Petley. 1970. Ignition loss and other properties of peats and clays from Avonmouth, King's Lynn \& Cranberry Moss. Geotechnique. Vol 20, no. 4 p 343-356.
4. De Haan, E. J. 1997. An overview of the mechanical behavior of peats and organic soils and some appropriate construction techniques. Proceedings of Conference on Recent Advances in Soft Soil Engineering. Huat \& Bahia (ed), Kuching, Sarawak.

5. Kaniraj, S. R. and Joseph, R.R. 1996. Geotechnical behavior of organic soils of North Sarawak. $4^{\text {th }}$ International Conference on Soft Soil Engineering, Vancouver Canada, October 4-6, 2006.

6. Mesri, G. 1973. Coefficient of secondary compression, J. Soil Mech. Found. Div, ASCE. Vol. 99, no. SMI.

7. O’Loughlin, C. D. \& B.M. Lehane. 2003. A study of the link between composition and compressibility of peat and organic soils. In Proceedings of $2^{\text {nd }}$ International Conference on Advances in Soft Soil Engineering and Technology, Putrajaya, Malaysia, ed. Huat et al.: 135-152.

8. Mesri, G. and Castro, A. 1987. $\mathrm{C}_{\alpha} / \mathrm{C}_{\mathrm{c}}$ concept and $\mathrm{K}_{\mathrm{o}}$ during secondary compression. Journal of Geotechnical Engineering, 123: 230-247. 